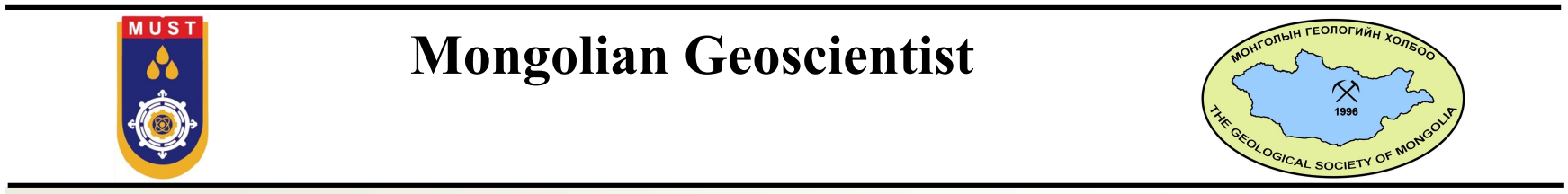

Original article

\title{
Petrology and mineralogy of the Ulaan Del Zr-Nb-REE deposit, Lake Zone, Western Mongolia
}

\author{
Geo-Info LLC, Ulaanbaatar 13311, Mongolia \\ *Corresponding author. Email: Sobats201902@gmail.com
}

Sanjsuren Oyunbat*

\section{ARTICLE INFO}

Article history:

Received 28 February, 2020

Accepted 31 May, 2020

\begin{abstract}
The Ulaan Del deposit is located in the Lake Zone, Western Mongolia. In the area, middle-late Devonian alkali dykes of the Khalzan Complex are hosted in the middlelate Cambrian granodiorite-tonalite of the Togthohiinshil Complex. The alkali dykes of the Khalzan complex comprise medium- to fine-grained syenite, microsyenite, syenite-porphyry and trachyte, trachyrhyolite, and trachyandesite. The dykes are replaced to silica, sericite, albite, fluorite and are brecciated. They crosscut by quartz and quartz-carbonate veinlets. The dykes contain zircon $(>0.19 \% \mathrm{Zr})$ with a total of rare earth elements oxides $>0.1 \%$. The host rocks of the Togtokhiinshil complex are mid-K, metaluminous, I- type granite, depleted in HFSE. Based on geochemical and mineralogical data, economic REE mineralization is concentrated in syenite and syenite porphyry of calc-alkaline high $\mathrm{K}$ to shoshonite series of Atype granite, emplaced at within a plate setting. Syenite dykes are enriched in REE. Ore minerals are zircon, apatite, sphene, monazite, xenotime, synchysite, parisite, fluorite and REE complex minerals, pyrite, rutile and limonite. Magmatic, metasomatic and hydrothermal processes significantly contributed to the formation of $\mathrm{Zr}, \mathrm{Nb}, \mathrm{REE}$ and $\mathrm{Y}$ mineralization at the Ulaan Del deposit.
\end{abstract}

Keywords: albite, feldspar, metasomatite, xenotime, alkali dykes

\section{INTRODUCTION}

The Ulaan Del deposit is located southwest of Khyargas Lake within the Lake Island arc terrane (Lake Zone) of the Northern Mongolian domain (Fig. 1). The Lake terrane contains several intact ophiolites (Khantaishir, Bayannuur, Geriin Nuruu and Agardagh), calcalkaline basalt, andesite (522 $\pm 13 \mathrm{Ma}$, Sm-Nd; Kovalenko et al., 1995, 1996), rhyolite, volcanoclastic rocks intruded by Late Cambrian -Ordovician syn-and post-tectonic diorite, granodiorite and granite (497 Ma, Kroener et al., 2007) covered by clastic sediments. Geological investigation of the region, including the Ulaan Del deposit area started in the early 1980 's by 1:200000 scale geological mapping (Samozvantsev et al., 1982) and an airborne geophysical survey on the scale of 1:50000 (Gavrilov et al., 1987, 1989 and 1990). In the early 1990's Minin et al. discovered anomaly A657 (later named Shar Tolgoi) during an airborne geophysical survey on the scale of

(C) The Author(s). 2020 Open access This article is distributed under the terms of the Creative Commons Attribution 4.0 International License (https://creativecommons.org/licenses/by/4.0/), which permits unrestricted use, distribution, and reproduction in any medium, provided you give appropriate credit to the original author(s) and source, provide a link to the Creative Commons license, and indicate if changes were made. 


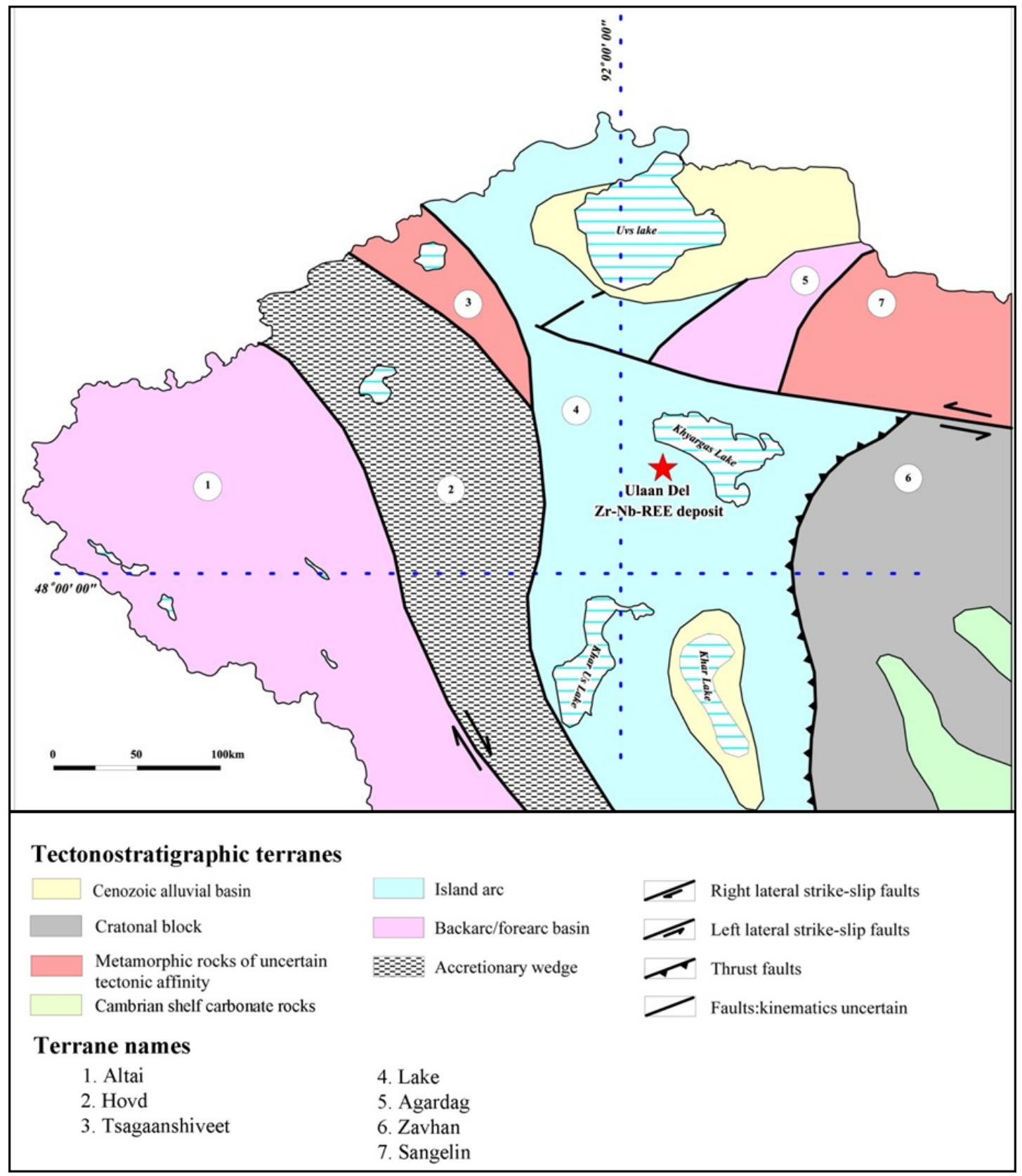

Fig. 1. Location of the Ulaan Del deposit in the terrane-tectonic map (Badarch et al., 2002)

1:50000 and explored it with a few drill holes and trenching (Fig. 2). From the exploration, the geological probable reserves were assessed at REE bearing ore of 19,900 tonnes of $\mathrm{Ta}_{2} \mathrm{O}_{5}$, 19,000 tonnes of $\mathrm{Nb}_{2} \mathrm{O}_{5}$ and $1.4 \mathrm{Mt}$ of $\mathrm{ZrO}_{2}$ (Minin et al., 1991).

Since 2009, geological prospecting and exploration works in the Ulaan Del deposit area (Fig. 2) were carried out by Geo-Info LLC, Mongolia, As a result, inferred and probable $(\mathrm{C}+\mathrm{P})$ reserves estimated $6.1 \mathrm{Mt}$ of ore at $0.16 \%$ $\sum$ TREO, $0.33 \% \mathrm{ZrO}_{2}, 0.05 \% \mathrm{Nb}_{2} \mathrm{O}_{5}$ and proved by the Mineral Resources Professional Council of Mongolia in 2018 (Oyunbat et al., 2018).

The Ulaan Del deposit comprises swarm stockwork-like alkaline dykes with Zr-Nb-REE mineralization (Fig. 2). This study discusses geology, petrography and geochemistry of the mineralized alkaline dykes at the Ulaan Del and includes a mineralogical study of REE bearing minerals. 


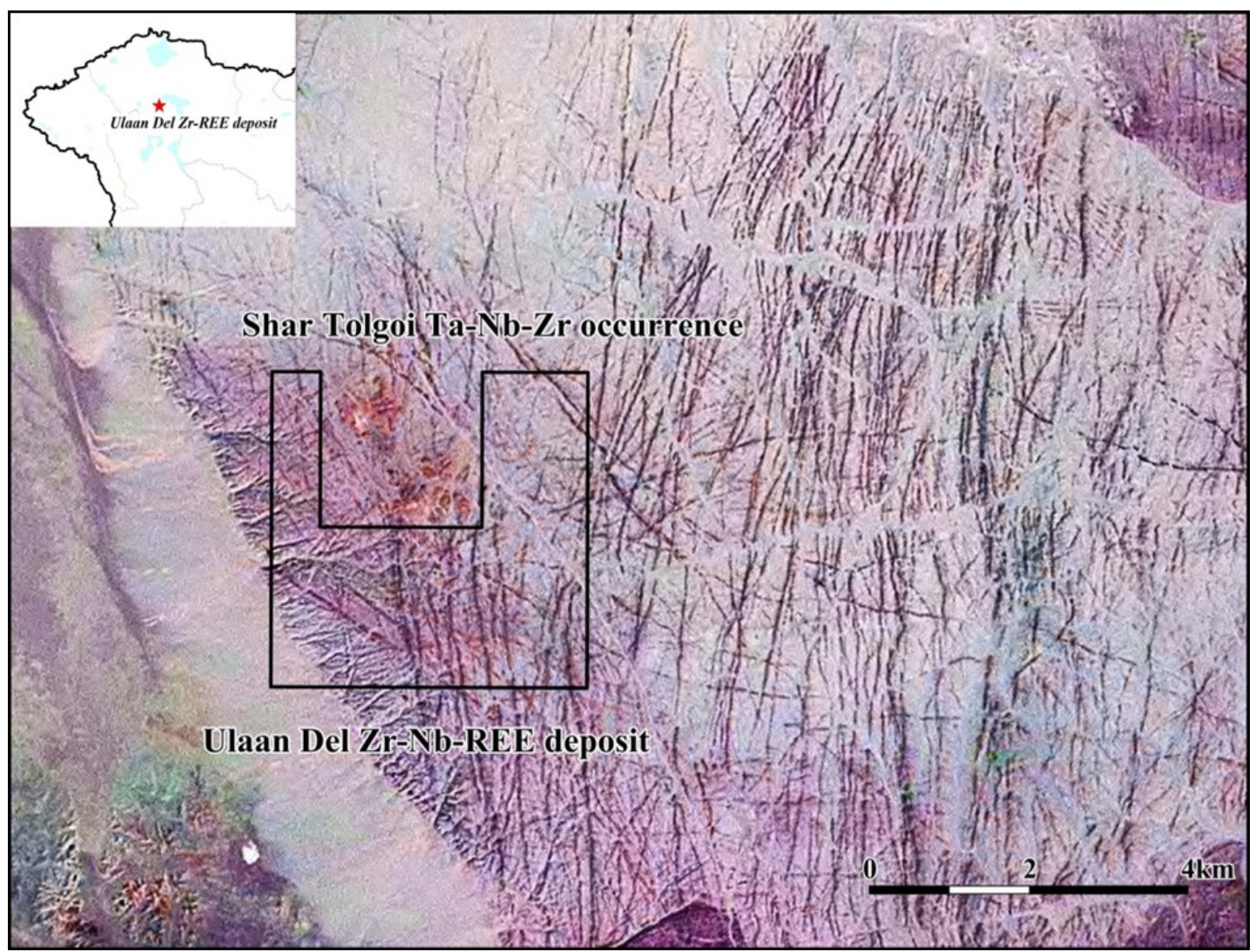

Fig. 2. Landsat image of the Ulaan Del Zr-Nb-REE deposit area. Location of the Shar Tolgoi Ta$\mathrm{Nb}-\mathrm{Zr}$ occurrence and the distribution of the ore-bearing alkaline dykes in the area

\section{REGIONAL GEOLOGY OF THE LAKE ZONE}

The Lake Zone represents one of the main tectonic domains of the Central Asian Orogenic Belt (CAOB) (Badarch et al., 2002). A number of the arc-related magmatic complexes distributed in the Lake Zone, Western Mongolia, which are considered as a result of exclusively oceanic crust subduction (Badarch et al, 2002, Kovalenko et al., 2004, Rudnev et al. 2012). This magmatism recorded the whole history from Late Proterozoic to Early Paleozoic including the formation of oceanic crust, subduction processes and arc-related magmatic activity (Sojeono et al., 2016, Rudnev et al., 2009) and post-orogenic magmatism (Yashina, 1982).

In the Lake Zone, two separate Early Paleozoic magmatic events were recognized (Sojeono et al, 2016), Middle Ordovician (460 Ma) and Late Devonian (376 Ma). Middle Ordovician magmatism produced gabbro to gabbro-diorite with mostly low to normal K- calc alkaline series plutonic rocks emplaced into the volcanosedimentary sequences. The Late Devonian granite suite with calc-alkaline high $\mathrm{K}$ to shoshonitic character intruded the gabbro-diorite and volcano-sedimentary sequences. The alkaline magmatism penetrating or crosscutting the hosting rocks as dykes, stocks, bodies chains of alkaline granite bodies, alkaline syenite and gabbroids developed along deep faults and their branches and along margins of the Caledonian uplifts, within the Lake Zone (Sojeono et al, 2016).

\section{LOCAL GEOLOGY OF THE ULAAN DEL DEPOSIT}

Geology of the Ulaan Del area is dominated by alkaline dykes of the Middle-Late Devonian Khalzan complex that is hosted in the MiddleLate Cambrian Togtokhiinshil granitoids complex.

Alkaline dykes at the Ulaan Del deposit area extend over $300-500 \mathrm{~m}$ along the strike with variable widths $(0.5-2 \mathrm{~m})$. The dykes show 
diverse composition from andesite to granite and syenite with micro to porphyritic texture. The dykes sometimes brecciated along strike and small breccia pipes can found within the area (Fig. 3).
A geological map of the "Central" mineralized area of the Ulaan Del deposit shown as an example (Fig. 4). The dykes are brecciated, oxidized, silicified and albitized with pyrite, fluorite, muscovite, chlorite, epidote and

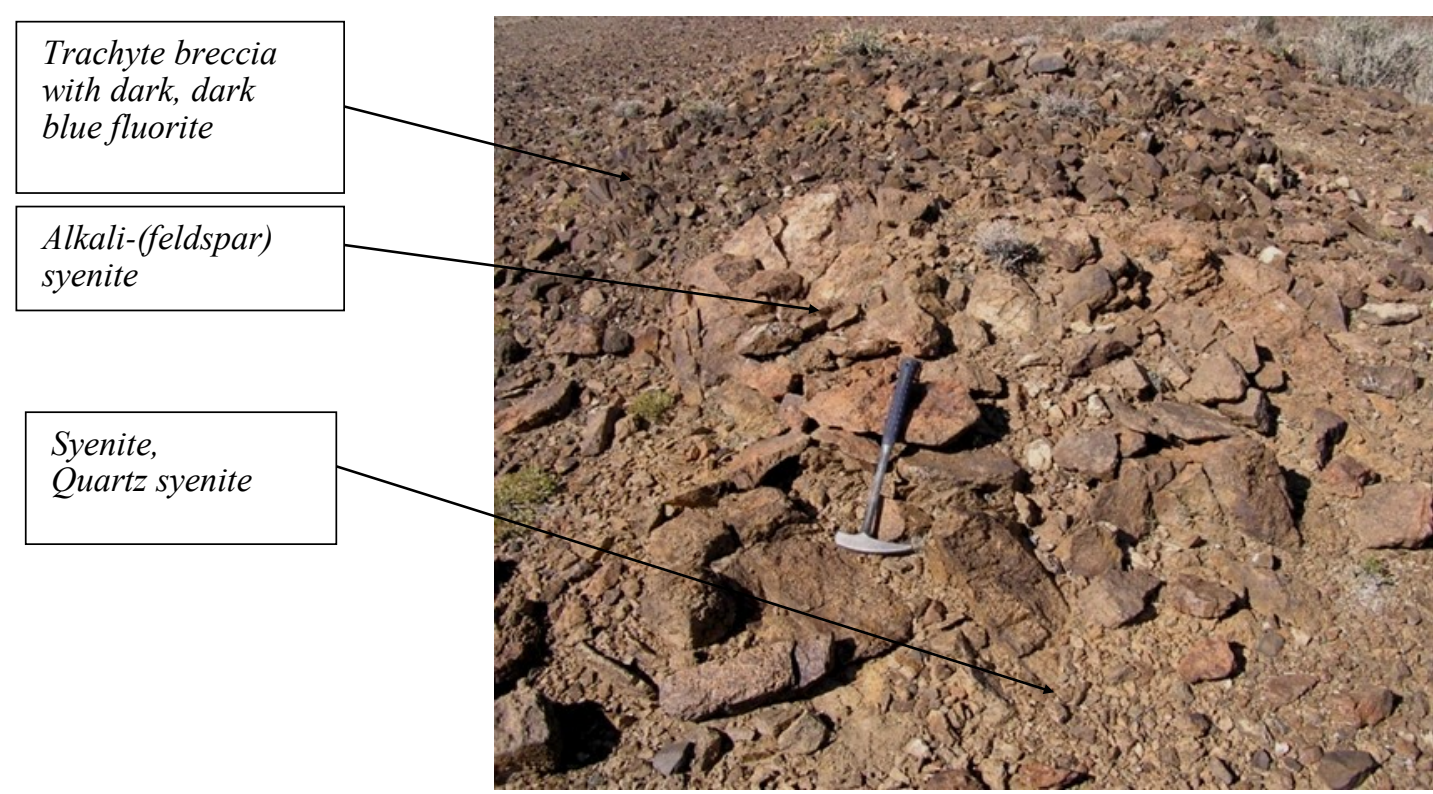

Fig. 3. Outcrop view of the breccia pipe $(8.5 \times 17 \mathrm{~m})$

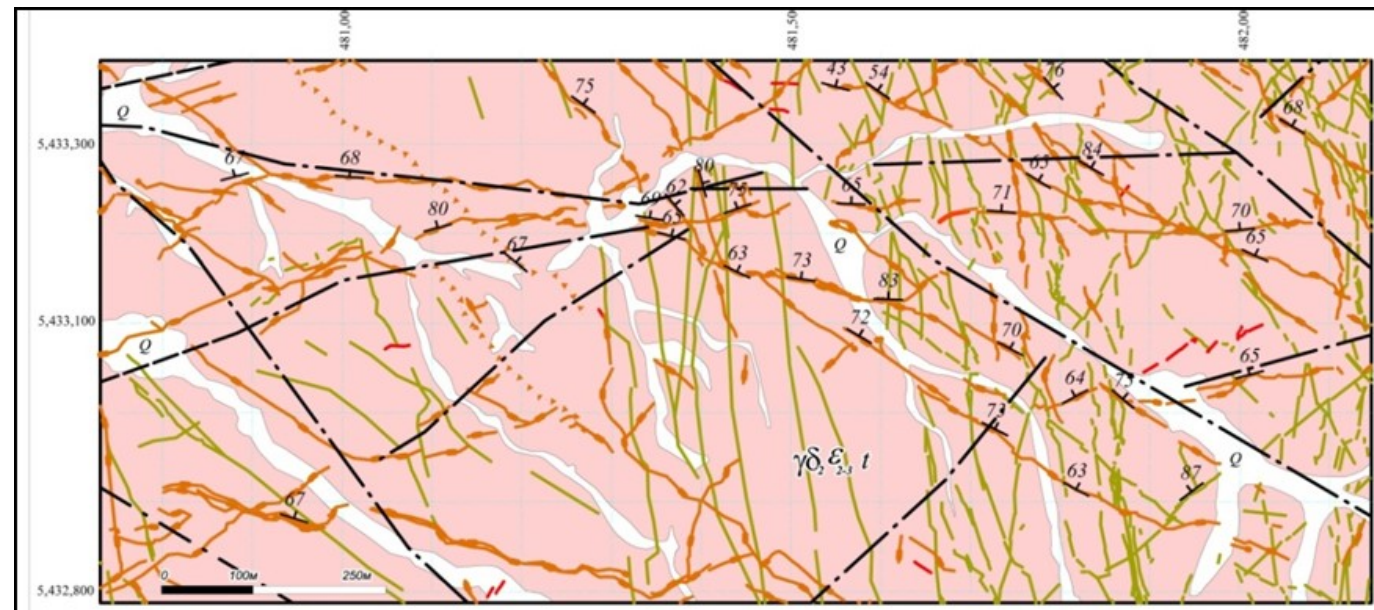

Explanation

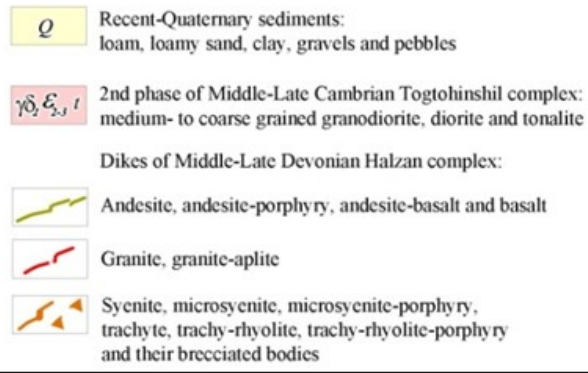

Fig. 4. Geological map of the Central area of the Ulaan Del deposit

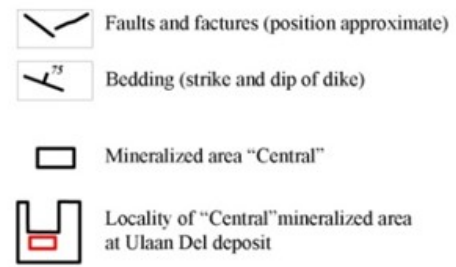


crosscut with quartz-carbonate-iron oxide thin veinlets. Medium to coarse-grained granodiorite -tonalite, diorite and quartz monzonite of the Togtokhiinshil complex commonly distributed in the Ulaan Del area, represent the second phase of the Complex.

REE mineralization associated with alkaline dykes of the Khalzan complex. The high-grade Zr-REE mineralization associated with potassium feldspar enriched or albititic rocks with iron oxide, fluorite-(carbonate) alteration. The main minerals of the REE are xenotime, zircon and parisite-synchysite, complex REEbearing minerals, monazite and apatite.

\section{METHODS AND MATERIALS}

More than 1000 rock samples collected, including channel and core samples. The sampling interval was about $25-40 \mathrm{~m}$, but near the mineralized, more fractured and altered parts, the sampling interval narrowed. Samples designated with their drill hole identifier followed by the depth in meters.

The mineralogical and chemical composition of the rocks, alteration, REE-bearing minerals and their spatial and temporal distributions where determined by various laboratory methods.

About 65 selected samples from various dykes investigated for their texture and mineral composition. Petrographic and mineralogical microscopic studies carried out at the Geoscience Center, Mongolian University of Science and Technology.

Totally 12 drill core and rock samples from metasomatically altered alkaline dykes and host quartz diorite selected for whole rock geochemistry. Major oxides of $\mathrm{SiO}_{2}, \mathrm{TiO}_{2}$, $\mathrm{Al}_{2} \mathrm{O}_{3}, \mathrm{FeO}, \mathrm{Fe}_{2} \mathrm{O}_{3}, \mathrm{CaO}, \mathrm{MgO}, \mathrm{Na}_{2} \mathrm{O}, \mathrm{K}_{2} \mathrm{O}$, $\mathrm{MnO}, \mathrm{P}_{2} \mathrm{O}_{5}, \mathrm{CO}_{2}$ (in wt.\%), and trace elements of $\mathrm{Ba}, \mathrm{Nb}, \mathrm{Sr}$, Ta and $\mathrm{Zr}$ (in ppm) determined by using XRF and rare earth elements $\mathrm{La}, \mathrm{Ce}, \mathrm{Pr}$, $\mathrm{Nd}, \mathrm{Sm}, \mathrm{Eu}, \mathrm{Gd}, \mathrm{Tb}, \mathrm{Dy}, \mathrm{Ho}, \mathrm{Er}, \mathrm{Tm}, \mathrm{Yb}$ and $\mathrm{Lu}$ (in ppm) analyzed by ICP-MS at the Central Geological Laboratory of Mongolia.

Mineral identification using an X-ray diffraction (XRD) instrument has done at the laboratory of the Physics Department, Mongolian Academy of Sciences, and Tomsk University, Russia. The instruments operated at $40 \mathrm{kV}$ voltage and a current $30 \mathrm{~mA}$. The data measured in the $2 \sigma$ range from five to $80^{\circ}$ step width of $0.02^{\circ}$ and measuring time $0.60 \mathrm{sec}$ per step.

The relationship of zircon and xenotime was determined using an electron probe microanalyzer (EPMA), with mineral liberation analysis (MLA) and alteration and REE minerals by energy-dispersive spectra (EDS) analysis and microscopic studies carried out in GTK, Finland.

\section{Petrography}

\section{RESULTS}

The Khalzan complex alkali dykes mostly represented by quartz syenite and microsyenite are fine to medium-grained pinkish, ranging from pale to reddish in color. Sometimes they are weakly brecciated and mainly replaced by albite, sericite-muscovite, carbonate, iron oxides and pyrite. The main rock forming minerals are plagioclase, K-feldspar, altered dark minerals and quartz. Phenocrysts are 0.1-0.8 $\mathrm{mm}$, and groundmass is $0.05-0.6 \mathrm{~mm}$ in size (Fig. 5).

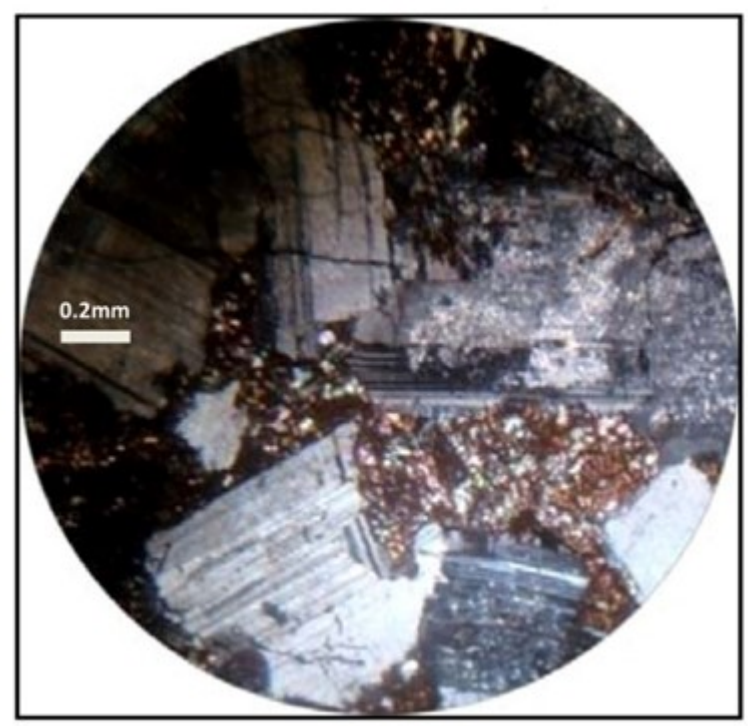

Fig. 5. Brecciated microsyenite (UD010). Phenocrysts interstitial spaces filled with muscovitesericite

Syenite-porphyry composed of K-feldspar (from $70-75 \%$ to $85-90 \%)$ or albite (70-75\%), goethite, hydrogoethite $(10-15 \%)$, few quartz grains, carbonate $(5-10 \%)$, pseudomorphs of chlorite with rutile (3-5\%) and sericite-muscovite $(5 \%)$, a minor amount of fluorite (3-5\%) and apatite (3 

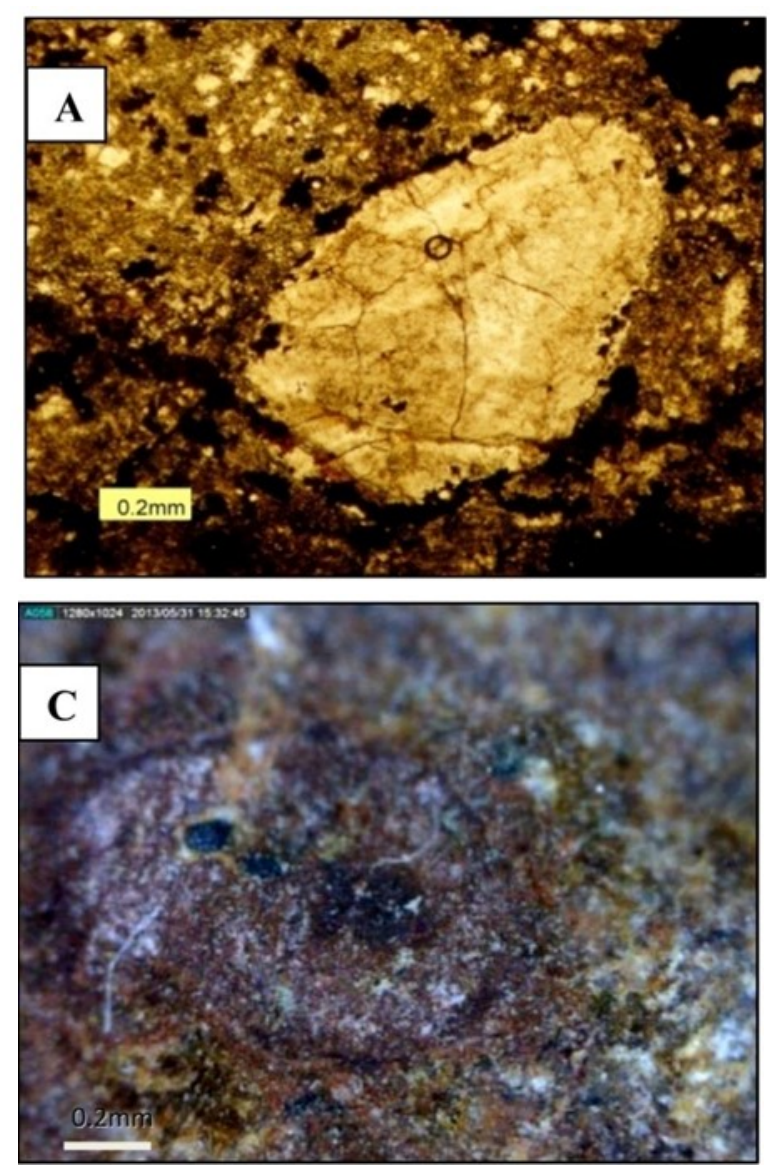

$-5 \%$ ). Accessory minerals are zircon, limonite, sphene and xenotime. K-feldspar phenocrysts are mainly replaced by albite and are reddish brown due to iron oxide dust. Sometimes the syenite-porphyry is brecciated with fragments enriched in oxide and cemented by carbonate and ore minerals. The sericite-muscovite and chlorite pseudomorphs filled the interstitial spaces between K-feldspar grains (Fig. 5). Some porphyritic textures formed by large, euhedral to anhedral perthitic aggregates of feldspar with quartz and muscovite-sericite.

Plagioclase grains are $0.01 \times 0.02 \mathrm{~mm}$ in size or small grains in interstitial spaces, and it associated with muscovite and sericite in volcanoclastic rocks. Plagioclase is mostly fresh and zoned, sometimes weakly replaced by secondary sericite and brecciated.

$K$-feldspar grains are 0.1-0.8 mm, sometimes up to $5 \mathrm{~mm}$ in size. Perthitic feldspar grains are

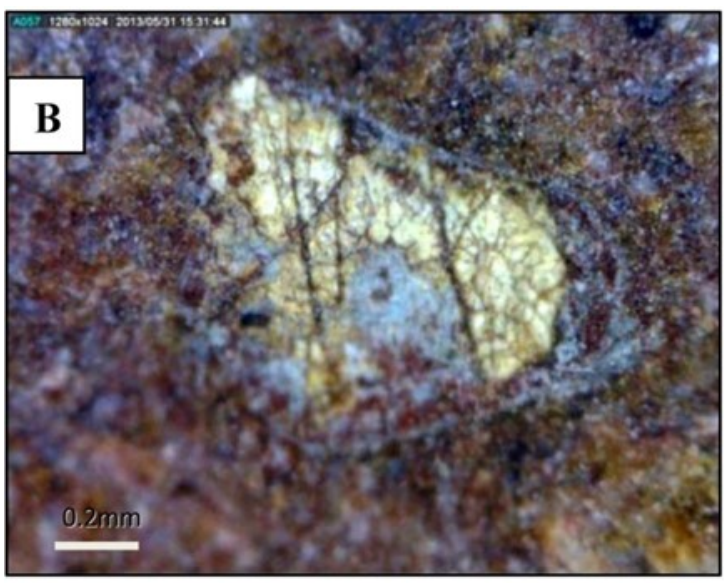

Fig. 6. K-feldspar in alkaline syenite. A. Kfeldspar or albite in perthite, B. K-feldspar crystals fractured and the fractures filled with iron oxides, C. K-feldspar completely replaced by ore minerals and host REE minerals

1-2 $\mathrm{mm}$ and are forming plate-like crystals. Twinning is very common with albite microgrowths (Fig. 6). Albite is fresh, prism-like, with muscovite micro-flakes and contains apatite, zircon and fluorite as inclusion.

One of the distinguishable features is the abundance of highly ordered microcline and albite established by XRD analysis and verified by optical microscopy. The highly ordered microcline forms the main part of perthitic alkali feldspar grains in trachytic or alkaline syenite (Fig. 7).

Goethite is pale gray, zoned and replaced with hydrogoethite from the edge and enveloped by muscovite flakes (Fig. 8).

Nests and lenses of iron-oxidized carbonates developed evenly within the dykes and host rutile, fine grains of zircon and apatite. Apatite grains as fine, prism like, irregular, isometric are observed as aggregates along microfractures, mostly along the edge of potassium feldspar 

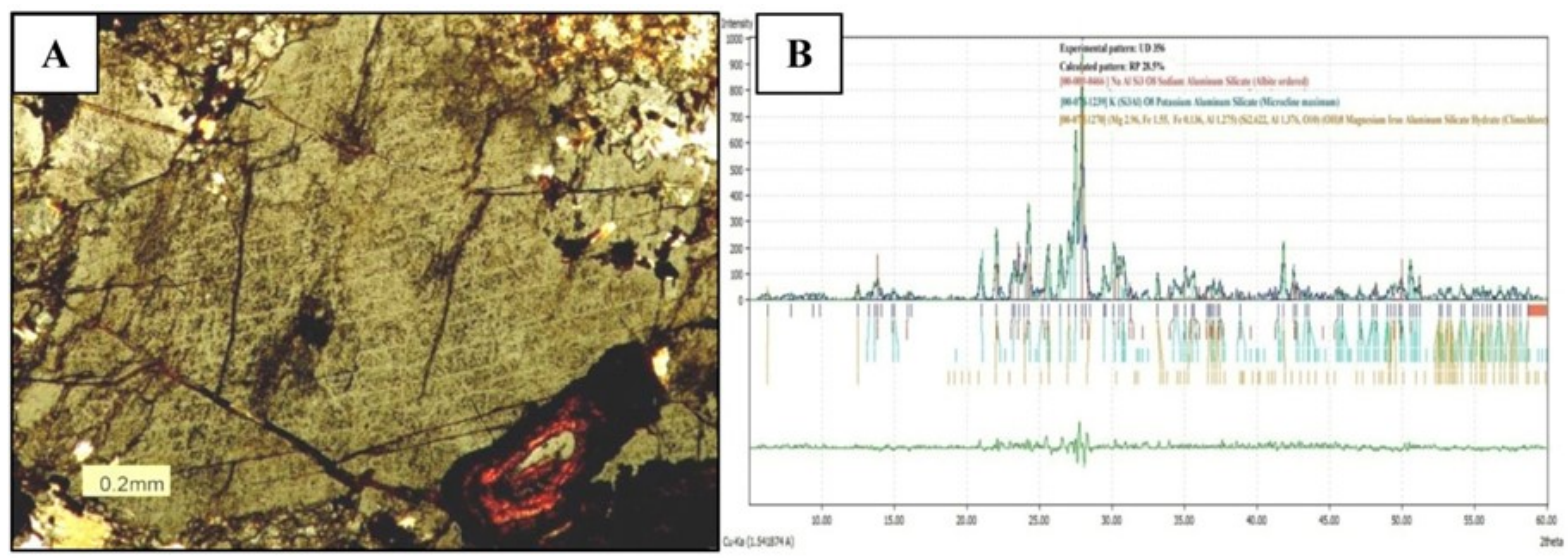

Fig. 7. Highly ordered cross-hatching microcline in alkaline rocks. A. Microcline and zoned goethite (cross polarized transmitted light). B. Quantitative XRD analysis of metasomatic rocks (albite, microcline)
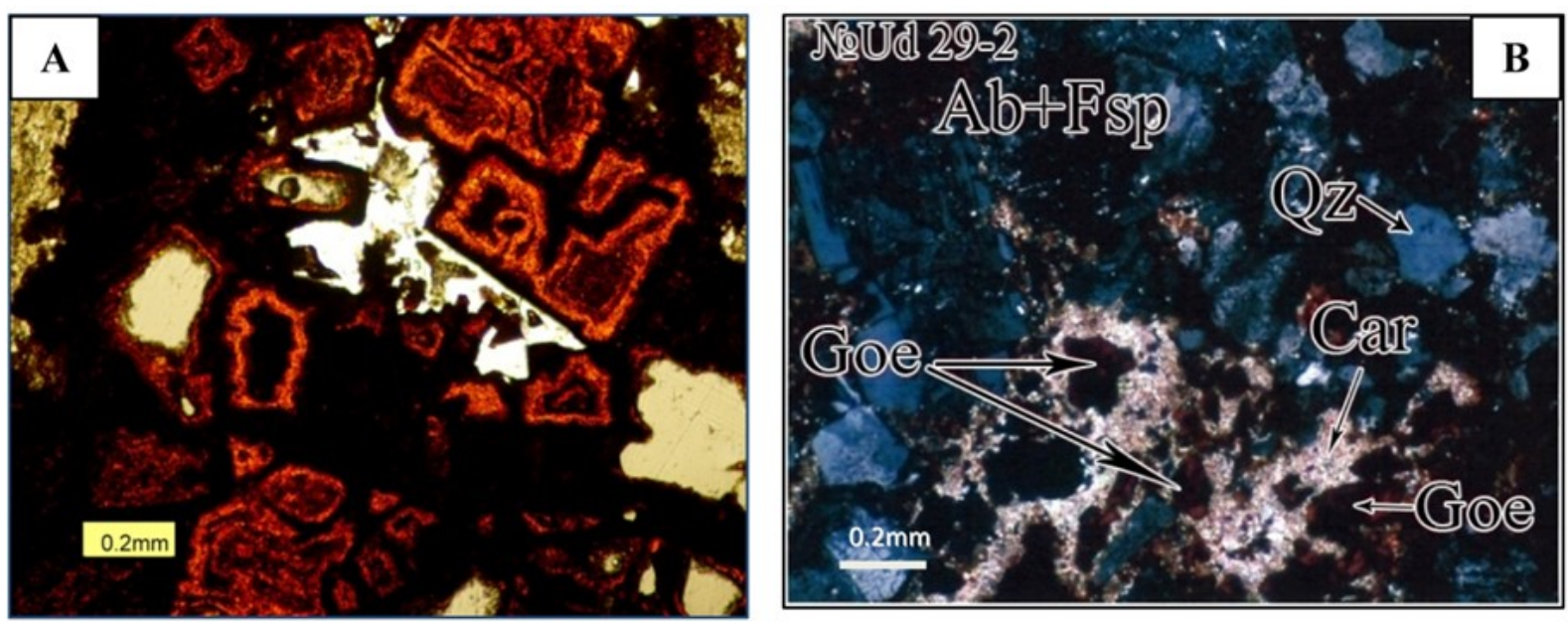

Fig. 8. A. Goethite zoned and replaced with hydrogoethite from the edge. B. Iron oxide lenses (Goe) with carbonate (Car) on albite-feldspar matrix $(\mathrm{Ab}+\mathrm{Fsp}), \mathrm{Qz}$-quartz grains

grains. Moreover, apatite is associated with clear rutile micrograins. Some carbonaceous aggregates are synchysite-parisite or REE carbonate minerals. Relatively larger lenses of carbonate minerals tinted by iron oxides and often show red or reddish-brown color. They include apatite, zircon, monazite and xenotime $(0.001-0.01 \mathrm{~mm})$ grains as inclusion. Fluorite, carbonate slender veinlets and lenses are often noted along fractures.

Accessory minerals. Sphene grains have prolonged shape, 0.01-0.06 $\mathrm{mm}$ in size, show dark brown color and occur very often. Zircon (0.03-0.05 $\mathrm{mm})$ dipyramidal, occurs as nests and micrograins. Monazite is (0.01-0.1 mm) pale, rectangle or plate like grains with a dark frame. Apatite is $(0.02-0.125 \mathrm{~mm})$ clear, forming hexagonal, short prism like grains. Synchysite is $(0.02-0.06 \mathrm{~mm})$ clear, pale to creamy brown, thick and short prism like grains and associated with dark framed grains or ore minerals. Fluorite $(0.5 \mathrm{~mm})$ is sometimes clear with a purple tint, filling the veinlets, spaces and fractures in the rocks. Typical fluorite crystals and xenomorth grains are associated with zircon, synchysite and xenotime (Fig. 9).

\section{Geochemistry}

Whole rock geochemical data are in Table 1, and REE data are summarized in Table 2.

The alkali dykes are fine- to medium grained, often porphyritic, weakly brecciated and affected by metasomatic alteration followed by mineralization. In the TAS diagram (Fig. 10) the Khalzan Complex rocks range from sublalkaline 

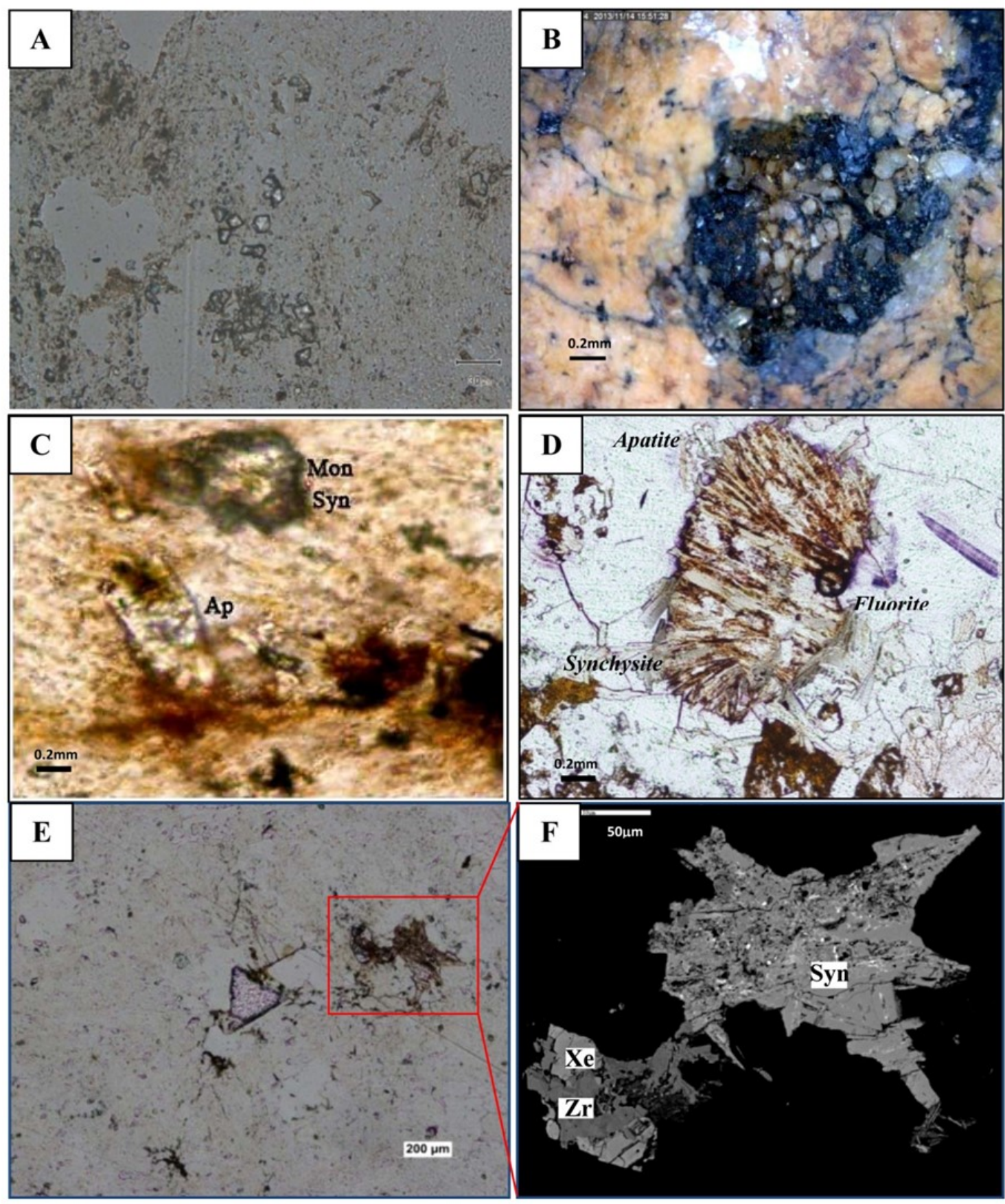

Fig. 9. Accessory minerals in alkaline dykes of the Khalzan complex. A. zircon grains, B. nests of zircon, C. apatite (Ap), monazite (Mon), synchysite (Syn), D. synchysite (Syn), fluorite, E. Goethite replaced by ore minerals with purple fluorite crystals, F. synchysite (Syn), zircon (Zr), Xenotime (Xe).

gabbro to monzonite and syenite, whereas the Togtokhiinshil Complex represented by diorite to granodiorite (Fig. 10).

The Khalzan Complex rocks are high-K to shoshonite series (Fig. 11), with high $\mathrm{Al}_{2} \mathrm{O}_{3}$ (Table 1) and ASI of $<1.1$, whilst the Togtokhiinshil Complex rocks plot in the low to
medium-K field (Fig. 11).

The REE patterns show that the Khalzan alkali syenite and monzonite are rich in LREE, and slightly depleted in HREE, where the host diorite of the Togtokhiinshil Complex shows a similar pattern, but with a low La, Ce and HREE composition in comparison to the monzonites 
Oyunbat, Mongolian Geoscientist 50 (2020) 45-62

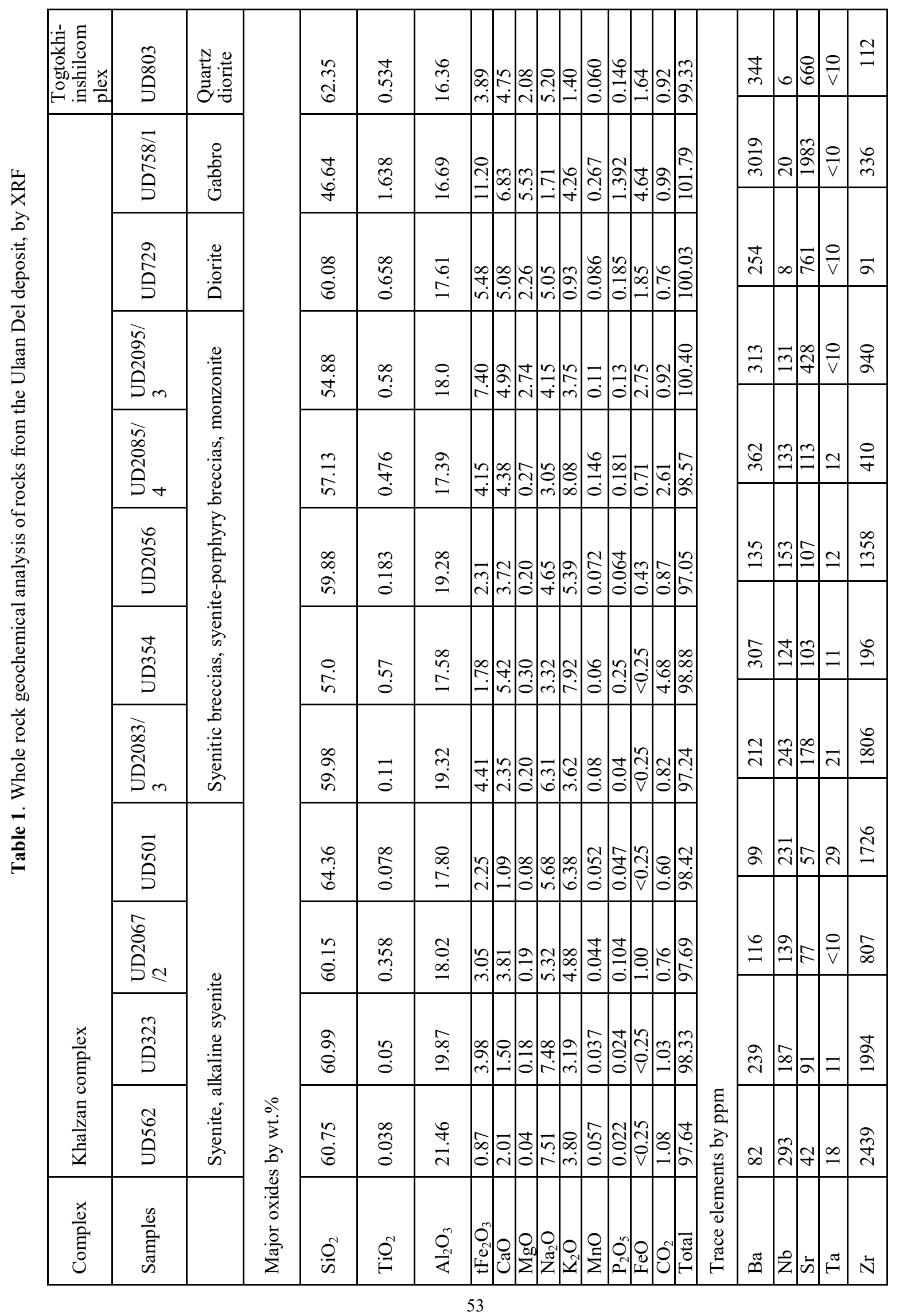




\section{$\mathrm{Na}_{2} \mathrm{O}+\mathrm{K}_{2} \mathrm{O}(\mathrm{vol}, \%)$}

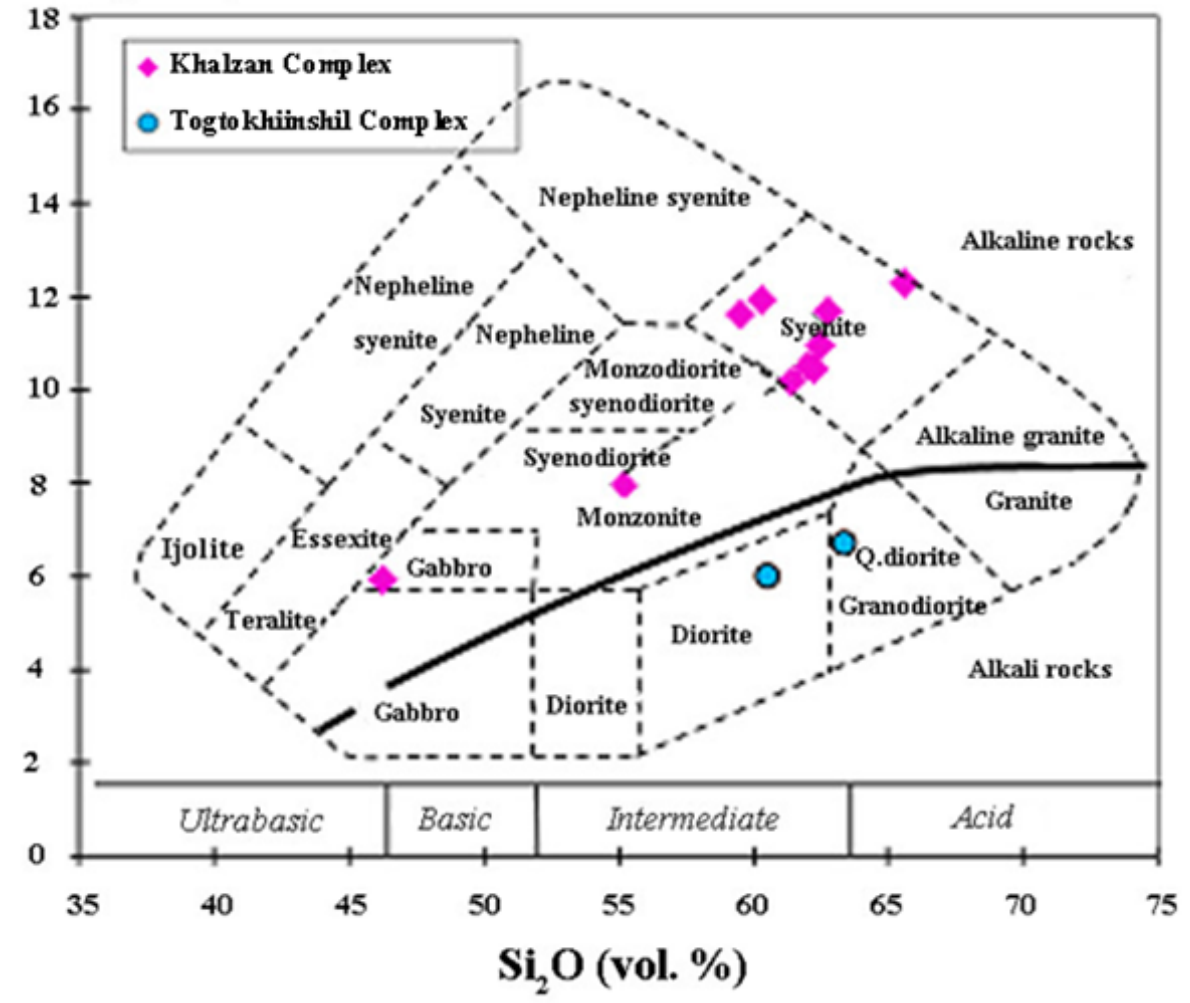

Fig. 10. TAS classification diagram (Le Maitre, 1989) for the Khalzan and Togtokhiinshil complex rocks in the Ulaan Del deposit area

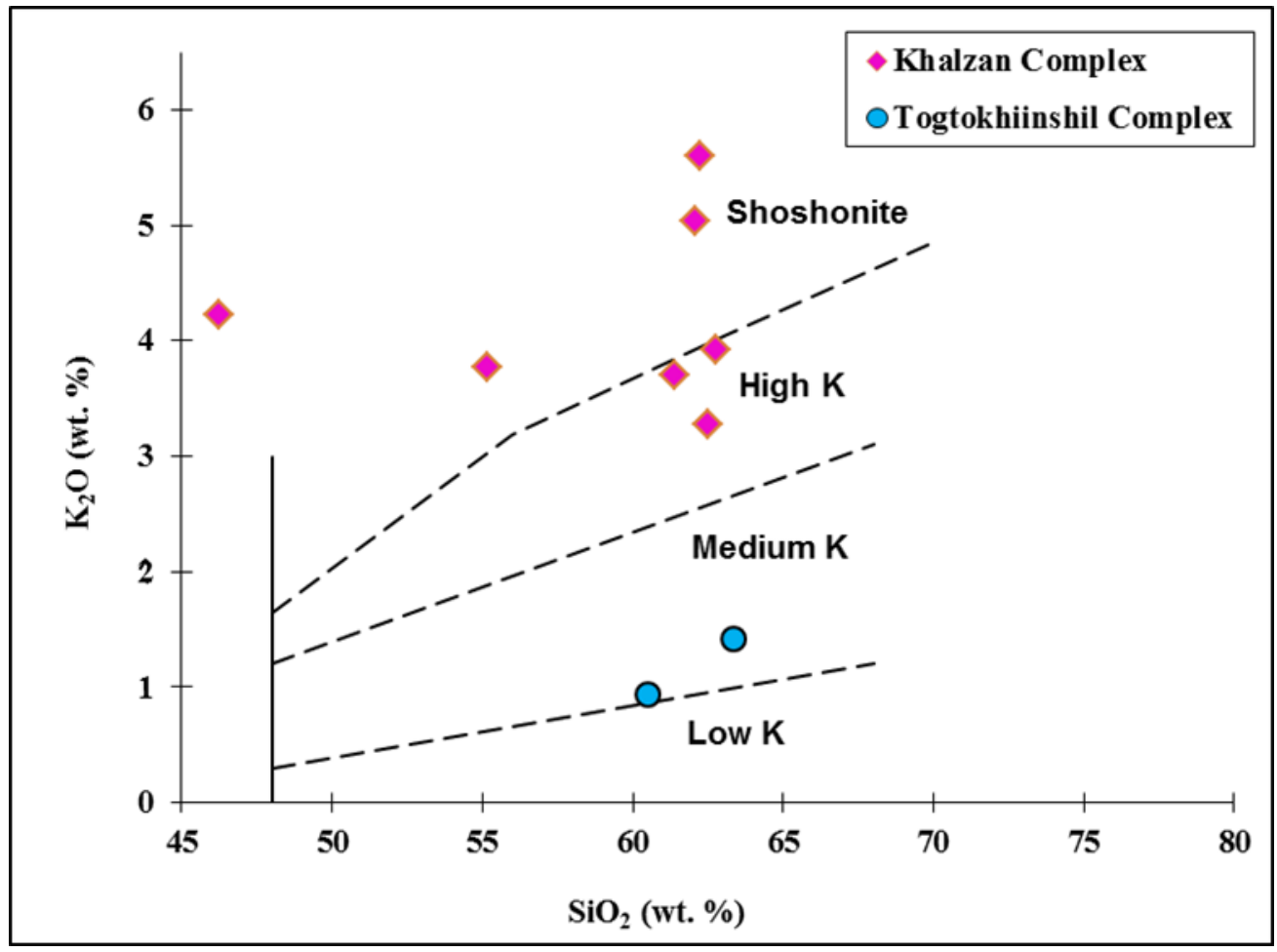

Fig. 11. $\mathrm{K}_{2} \mathrm{O}$ vs $\mathrm{SiO}_{2}$ variation diagram with subdivisions of Le Maitre (1989) for the Khalzan and the Togtokhiinshil complex rocks in the Ulaan Del deposit area 
and syenites (Table 2 and Fig. 12).

\section{Mineralogy}

Detailed EDS, EPMA and MLA analyses carried out to investigate the alteration and REE bearing minerals. Selected parts of the altered rocks and accessory minerals were analyzed for their chemical composition by the REE spectrum distribution method.

REE distribution pattern of minerals

The analyzed metasomatic rocks are enriched in

Table 2. REE composition of alkaline dykes in the Ulaan Del

\begin{tabular}{|c|c|c|c|c|c|c|c|}
\hline $\begin{array}{c}\text { Sample } \\
\text { ppm }\end{array}$ & UD323 & UD501 & UD729 & UD2056 & UD2095/3 & UD2067/2 & UD2085/4 \\
\hline $\mathrm{La}$ & 128 & 140 & 30 & 117 & 78 & 98 & 60 \\
\hline $\mathrm{Ce}$ & 212 & 326 & 37 & 212 & 183 & 213 & 146 \\
\hline $\mathrm{Pr}$ & 52 & 75 & 30 & 18.08 & 17.96 & 18.08 & 13.12 \\
\hline $\mathrm{Nd}$ & 117 & 115 & 50 & 58.98 & 59.4 & 62.94 & 57.49 \\
\hline $\mathrm{Sm}$ & 30 & 30 & 30 & 11.28 & 13.32 & 12.19 & 14.22 \\
\hline $\mathrm{Eu}$ & & & & 0.97 & 1.25 & 1.13 & 2.02 \\
\hline $\mathrm{Gd}$ & 6.95 & 22,57 & 3.1 & 13.33 & 14.19 & 15.08 & 14.39 \\
\hline $\mathrm{Tb}$ & 0.98 & 3,73 & 0.42 & 2.16 & 2.44 & 2.06 & 2.41 \\
\hline $\mathrm{Dy}$ & 6.03 & 24,52 & 2.05 & 11.56 & 13.26 & 10.47 & 13.97 \\
\hline $\mathrm{Ho}$ & 1.13 & 4,44 & 0.35 & 2.42 & 2.64 & 2.03 & 2.61 \\
\hline $\mathrm{Er}$ & 3.57 & 14,35 & 0.99 & 7.77 & 8.38 & 8.94 & 8.17 \\
\hline $\mathrm{Tm}$ & 0.51 & 2 & 0.12 & 1.13 & 1.22 & 0.89 & 1.14 \\
\hline $\mathrm{Yb}$ & 3.65 & 14,82 & 0.82 & 7.77 & 8.1 & 6.26 & 7.6 \\
\hline $\mathrm{Lu}$ & 0.53 & 2,04 & 0.11 & 1.1 & 1.17 & 0.91 & 1.1 \\
\hline
\end{tabular}

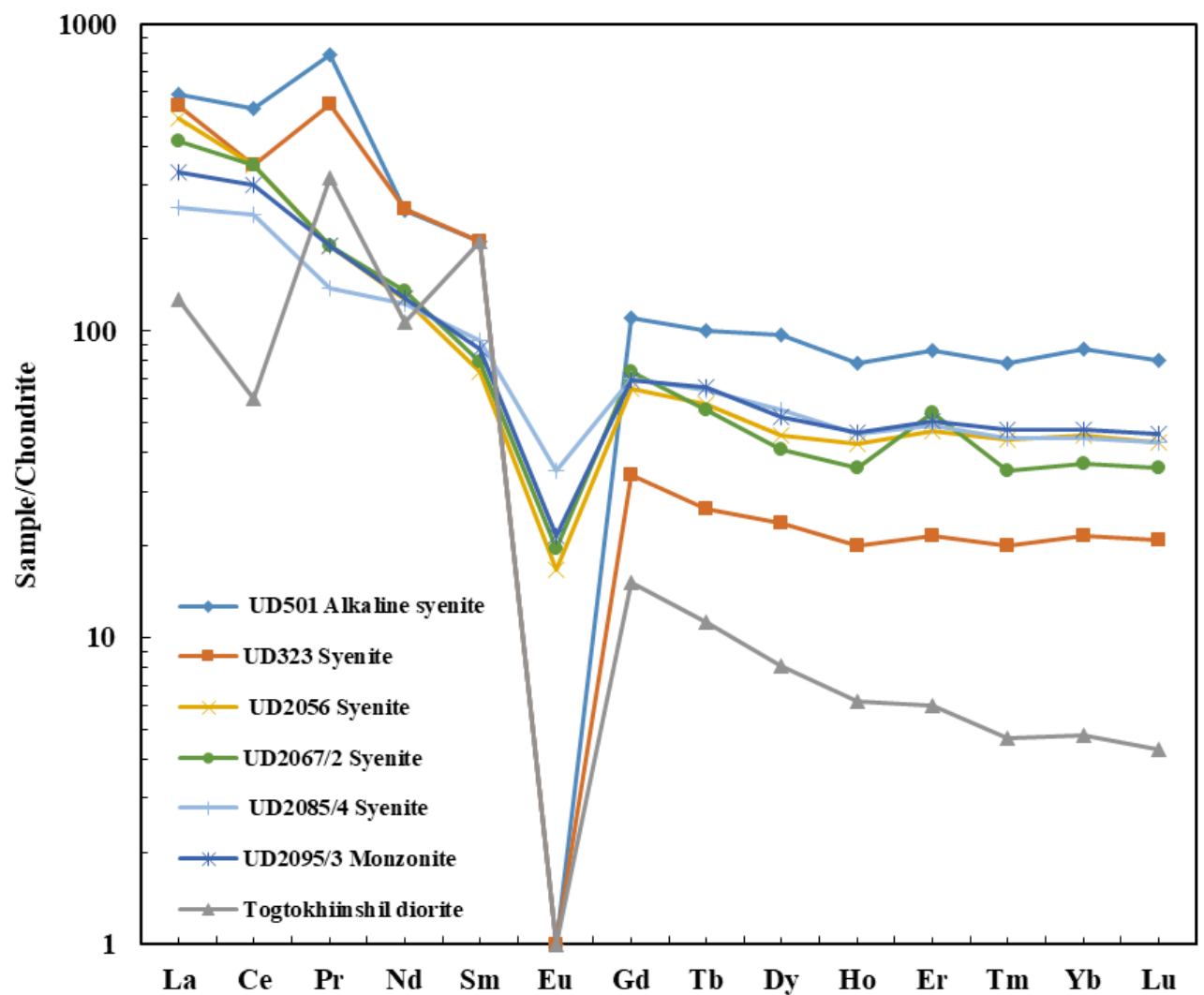

Fig. 12. Chondrite normalized REE distribution pattern of rocks from the Ulaan Del area. (C1 chondrite normalization by Sun and McDonough, 1989) 
$\mathrm{K}$ and $\mathrm{Na}$, silicified and iron oxidized (Fig. 13). Yttrium detected in different grains together with phosphorus spectra that indicate xenotime. Zircon is associated with xenotime and it is edging or framing xenotime in the same grains (Fig. 14). The REE distribution patterns showed the $\mathrm{Ce}, \mathrm{La}, \mathrm{F}, \mathrm{Y}, \mathrm{P}$ and $\mathrm{Zr}$ spectra. The La-Ce-F spectra are in the same grains that may indicate the composition of synchysite and parisite (Fig. $15)$.

REE distribution patterns are a responsive indicator for the formation of magmatic and metasomatic rocks. Three types of REE distribution patterns can identified within the studied samples:

- Low or primitive REE distribution patterns in medium-grained quartz monzodiorite, monzodiorite with rare pyrite phenocrysts indicate a moderate enrichment of both
LREE and HREE.

- Silicified alkaline trachytic rocks show the highest grade of $\mathrm{Zr}$. The general trend shows a higher amount of LREE (La-Ce group) and moderate or low HREE.

- Silicified and albitized alkaline syenite, microsyenite rocks with HREE or yttrium. The third type of REE distribution pattern unrelated to rock type, whether syenite or alkaline (albitized) syenite. This REE distribution may refer to "enriched type", due to its higher grade for HREE.

\section{REE- bearing minerals and assemblages}

Zircon is pure, less polluted. Zircon content is zirconium 35.35-46.07\%, oxygen $28-34.31 \%$, silica $12.17-14.73 \%$ and others $11.2-18.17 \%$.

Synchysite-parisite constituent Ce $16.37 \%$, La $9.40 \%, \mathrm{O} 43.85 \%, \mathrm{C} 15.5 \%$, Ca $8.38 \%$ and
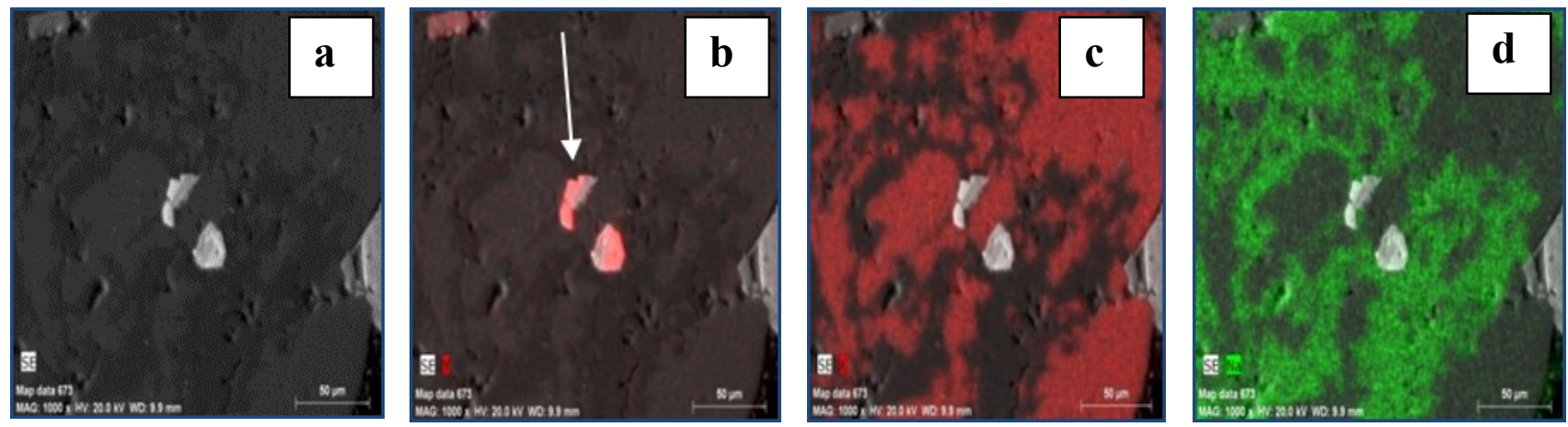

Fig. 13. Yttrium and Na-K distribution patterns. a. General view, b. yttrium, c. potassium, d. sodium distribution patterns

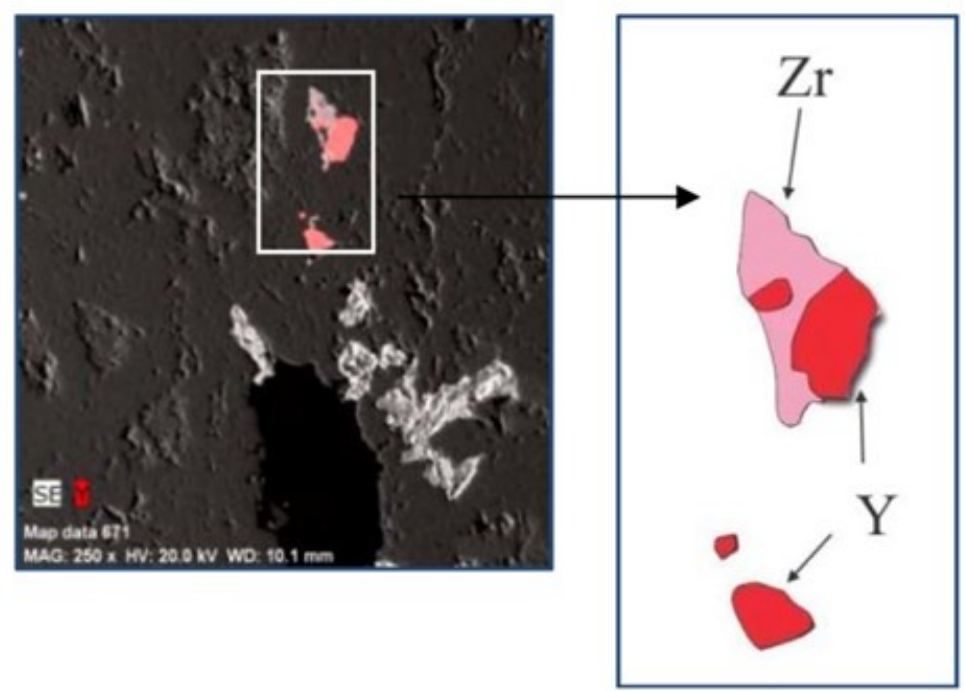

Fig. 14. Xenotime-zircon grain (Zoom 250X, HV 20.0, WD $10.1 \mathrm{~mm}$ ) 
others $6.5 \%$ in trachytic syenite rocks.

Xenotime - its elemental composition is complex, containing HREE's. Y 30.11\%, Yb $2.11 \%$, Gd $2.31 \%$, Dy $5.37 \%$, Er $3.17 \%$, Lu $0.38 \%$, and others $56.55 \%$.

There are two types of REE minerals that are contained complex HREE and LREE. The HREE (yttrium group) consists of Y 28.65\%, Gd $2.48 \%$, Dy $8.22 \%$, Er $4.29 \%$, Yb $3.52 \%$, and other elements 52.84\%. The LREE (La-Ce group) consists of $\mathrm{La} 10.29 \%$, Ce $10.21 \%$, and also Nd $4.23 \%$, Th $3.92 \%$, F $18.43 \%$ and other elements of $52.93 \%$.

A representative sample of metasomatic rocks (UD398) was analyzed using MLA. The sample crushed into 215571 grains, then 258477 times attacked by X-ray beam (Fig. 16), and mineral composition is shown in Table 3. The analysis showed a close relationship between xenotime and zircon.

Analyzed rock sample consists of potassium feldspar $(81.67 \%)$, muscovite $(8.07 \%)$, quartz $(4.2 \%)$ and goethite $(1.9 \%)$. REE minerals are parisite-synchysite, xenotime $(0.84 \%)$ and apatite. Zircon $(0.86 \%)$ is almost the same amount of that for xenotime $(0.84 \%)$.

Dykes at the Ulaan Del deposit entirely silicificated, albitized and microclinized. The main REE-bearing minerals are xenotime, parisite, synchysite, monazite, apatite and zircon. The complex HREE and LREE-bearing carbonate and phosphate minerals were identified. Xenotime and zircon are closely associated.
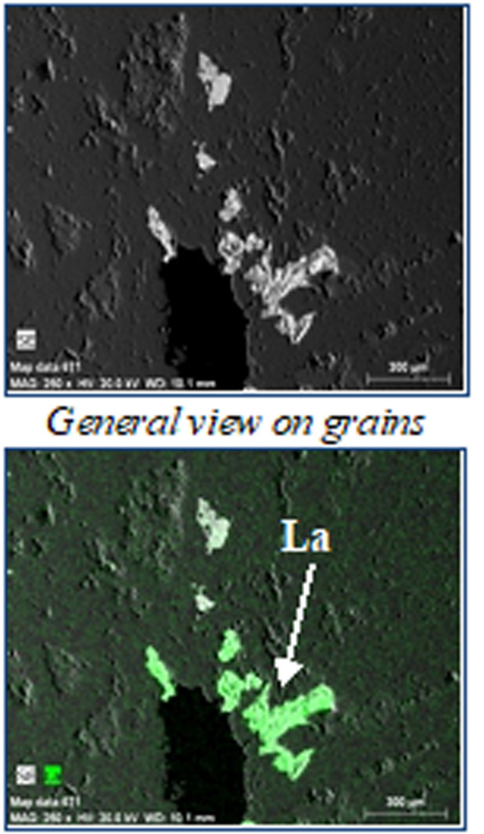

Lantconinon (La)

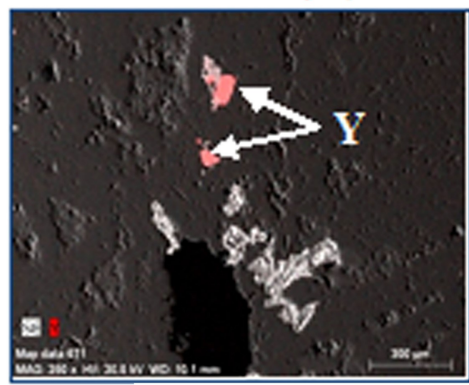

Yttrium (Y)

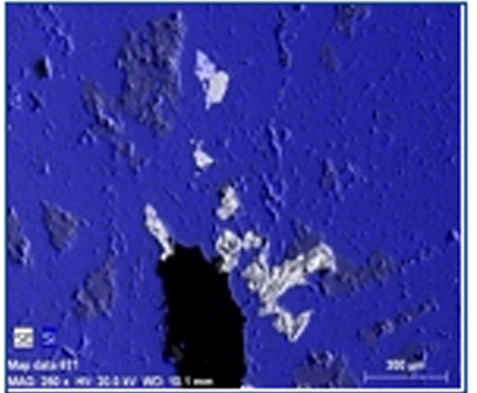

Silica $(\mathrm{Si})$

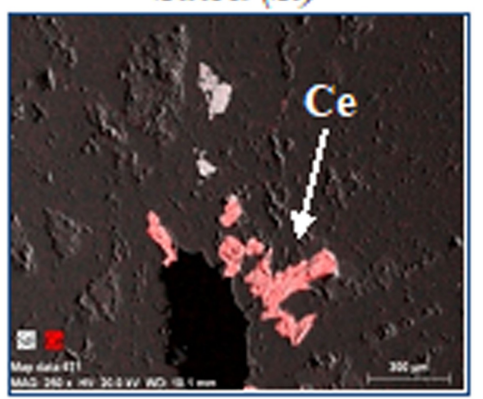

Cerium $(\mathrm{Ce})$

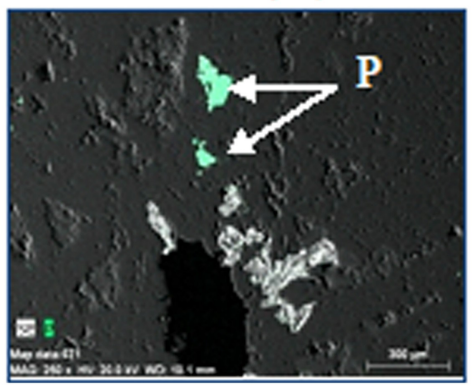

Phosphorus (P)

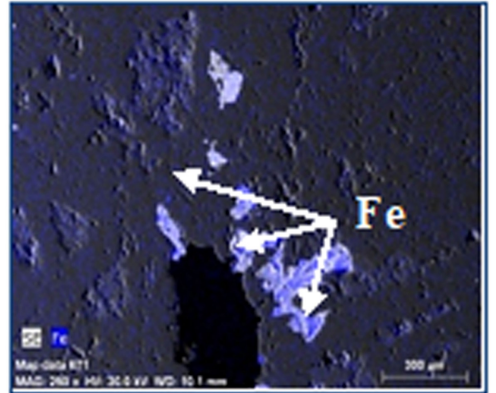

$\operatorname{Iron}(\mathrm{Fe})$

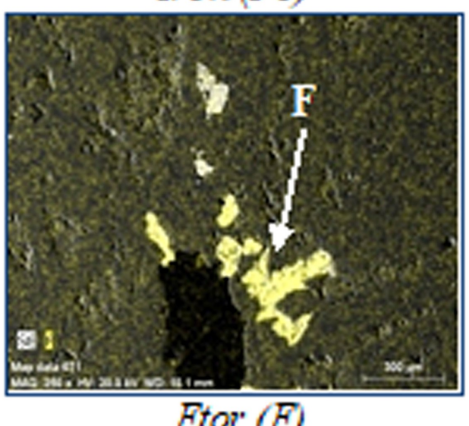

Ftor $(F)$

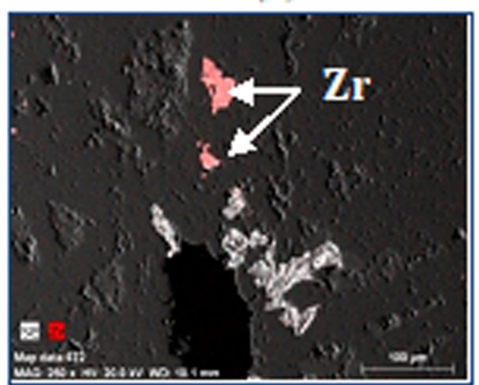

$\operatorname{Zircon}(\mathrm{Zr})$

Fig. 15. REE distribution patterns in metasomatic rocks (Zoom 250X) 


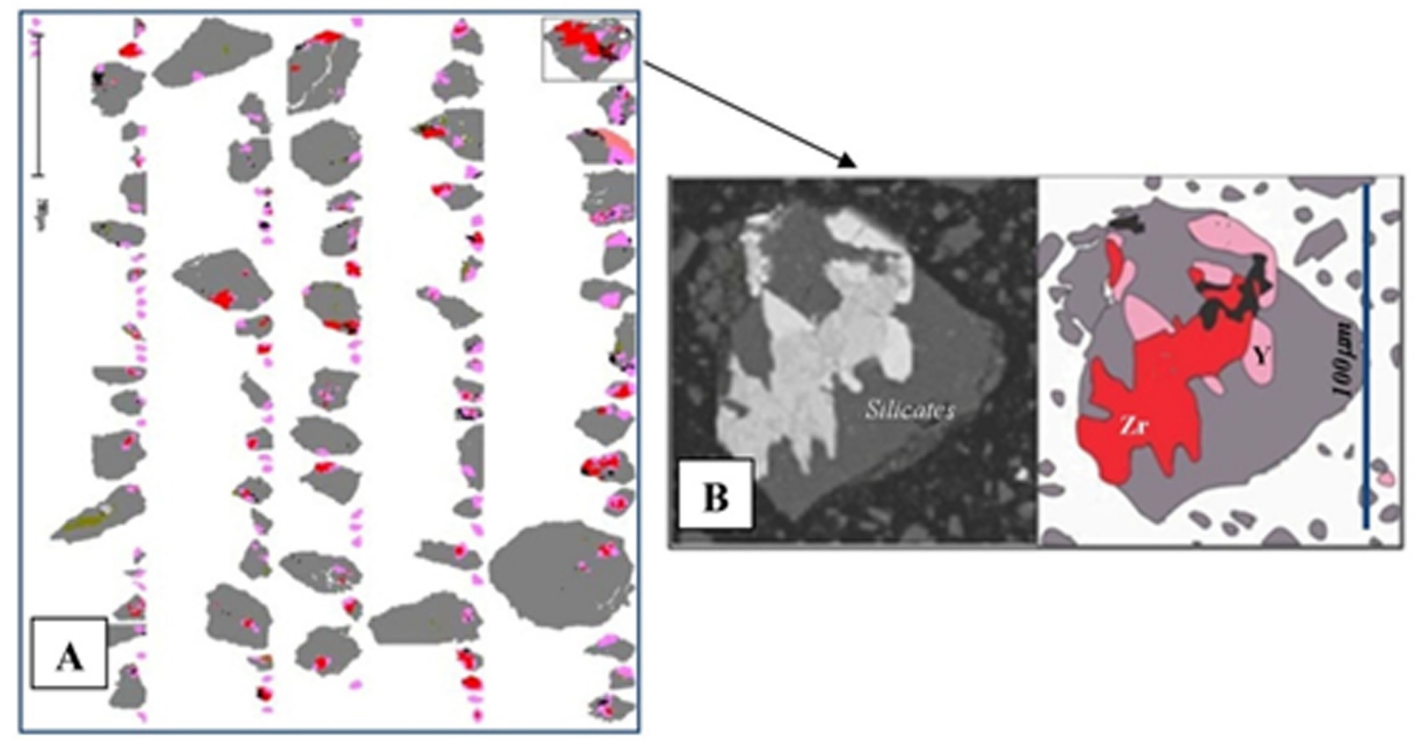

Fig. 16. Xenotime and zircon distribution, A. General view on grains attacked by X-ray beam, B.Xenotime (Y) and zircon $(\mathrm{Zr})$

Table 3. Mineral composition of selected rocks sample UD398

\begin{tabular}{|c|c|c|c|c|}
\hline Mineral & Chemical composition & Vol, \% & $\begin{array}{l}\text { Number of } \\
\text { grains }\end{array}$ & Density $\mathrm{g} / \mathrm{cm}^{3}$ \\
\hline Quartz & $\mathrm{SiO}_{2}$ & 4.20 & 2105 & 2.65 \\
\hline Plagioclase & $\mathrm{NaAlSi}_{3} \mathrm{O}_{8}-\mathrm{CaAl}_{2} \mathrm{Si}_{2} \mathrm{O}_{8}$ & 0.06 & 142 & $2.62-2.76$ \\
\hline $\begin{array}{l}\text { Potassium } \\
\text { feldspar }\end{array}$ & (KA1Si3O8) & 81.67 & 170777 & $2.54-2.75$ \\
\hline Muscovite & $\mathrm{KAl}_{2}\left[\mathrm{AlSi}_{3} \mathrm{O}_{10}\right][\mathrm{OH}]_{2}$ & 8.07 & 19125 & $2.76-3.1$ \\
\hline Biotite & $\mathrm{K}\left(\mathrm{Mg}, \mathrm{Fe}^{2+}\right)_{3}\left(\mathrm{Si}_{3} \mathrm{Al}\right) \mathrm{O}_{10}(\mathrm{OH}, \mathrm{F})_{2}$ & 0.02 & 120 & $2.7-3.3$ \\
\hline Chlorite & $\mathrm{Mg}_{3} \mathrm{Si}_{4} \mathrm{O}_{10}(\mathrm{OH})_{2} \cdot \mathrm{Mg}_{3}(\mathrm{OH})_{6}$ & 0.66 & 8219 & $2.6-3.3$ \\
\hline Zircon & $\mathrm{Zr}\left[\mathrm{SiO}_{4}\right] \mathrm{ZrO}_{2}-67,1 ; \mathrm{SiO}_{2}-32,9$ & 0.86 & 1861 & $4.68-4.71$ \\
\hline Parisite & $\begin{array}{l}\mathrm{Ca}(\mathrm{Ce}, \mathrm{La})\left(\mathrm{CO}_{3}\right)_{3} \mathrm{~F}_{2}: \mathrm{CaO}-3-10 ; \mathrm{Ce}_{2} \mathrm{O}_{3^{-}}-22-31 ; \\
\mathrm{La}_{2} \mathrm{O}_{3}-27,3-33,1 ; \mathrm{CO}_{3}-22,9-24,6 ; \mathrm{F}-6-7 .\end{array}$ & 0.06 & 141 & 4.36 \\
\hline Xenotime & $\mathrm{Y}\left[\mathrm{PO}_{4}\right]$, xenotime group of minerals $Y_{V O}-\mathrm{Ce}$ & 0.84 & 2551 & 4.8 \\
\hline Apatite & $\begin{array}{l}\mathrm{Ca}_{10}\left(\mathrm{PO}_{4}\right)_{6}(\mathrm{OH}, \mathrm{F}, \mathrm{Cl})_{2} \\
(\mathrm{CaO}): 53-56 \% ; \mathrm{P}_{2} \mathrm{O}_{5}: 41 \%\end{array}$ & 0.03 & 62 & $3.2-3.4$ \\
\hline Calcite & $\mathrm{CaCO}_{3}$ & 0.05 & 140 & 2.71 \\
\hline Fluorite & $\mathrm{CaF}_{2}$. Yttrium and cerium presented & 0.05 & 88 & $\begin{array}{l}3.18 \mathrm{Y}, \\
\text { If Ce present- } \\
\text { ed 3.3-3.6 }\end{array}$ \\
\hline $\begin{array}{l}\text { Chalcopy- } \\
\text { rite }\end{array}$ & $\mathrm{CuFeS}_{2}$ & 0.06 & 39 & 4.3 \\
\hline Sphalerite & $\mathrm{ZnS}, \mathrm{Fe}$ up to $26 \%$ & 0.00 & 2 & $4.08-4.1$ \\
\hline Pyrite & $\mathrm{FeS}_{2}$ & 0.03 & 27 & $4.9-5.2$ \\
\hline Psylomelan & $\mathrm{mMnO} \cdot \mathrm{MnO}_{2} \cdot \mathrm{nH}_{2} \mathrm{O}$ & 0.03 & 41 & $4.0-4.7$ \\
\hline $\begin{array}{l}\text { Ferrum } \\
\text { oxides }\end{array}$ & & 0.25 & 238 & \\
\hline Chromite & $\mathrm{FeCr}_{2} \mathrm{O}_{4}$ & 0.33 & 603 & $4.5-4.8$ \\
\hline Goethite & a-FeOOH & 1.93 & 4799 & \\
\hline Iron & & 0.34 & 305 & \\
\hline Unclassified & & 0.45 & 4186 & \\
\hline Total & & 100.00 & 215571 & \\
\hline
\end{tabular}




\section{DISCUSSION}

The genesis of REE-bearing rocks in the Ulaan Del area

The results of the petrographical, geochemical, and mineralogical investigations show that the REE mineralization bearing rocks of the Ulaan Del deposit is metasomatically altered syenite and syenite porphyries of the Khalzan Complex. There is a tendency that REE-bearing quartzalbite metasomatism was generated "selectively". It means that metasomatic alteration has not developed in all rock types in the area. Primarily, it was affecting only syenitic rocks in the outer contact zones.

There are many hypotheses on syenite genesis like partial melting of the metasomatic altered mantle (Lynch et al., 1993; Platt, 1996), alkali and alkaline basaltic magma differentiation (Thorpe and Tindle, 1992; Civetta et al., 1998; Ronga et al., 2010), melting of floor basalts (Sisson et al., 2005; Bonin, 2007; Jahn et al., 2009), and magma mixing with crusts (Marks and Markl, 2001).

The Togtokhiinshil Complex rocks are formed from depleted LIL and HFS sources. Therefore, it has no relation to the REE mineralization. However, it has noted that the Togtokhiinshil Complex includes an alkaline gabbro. Another proposition is that syenitic rocks may have generated from a primary enriched magma source and REE enrichment was due to subsequent metasomatism.

\section{Origin of mineralization}

The genesis of HFSE and REE mineralization associated with the peralkaline rocks is not well understood whether the mineralization is magmatic, hydrothermal, or a combination of the two (Dostal, 2016). The extensive fractional crystallization played a significant role for rare metal enrichment.

However, the mineralization is typically associated with altered alkaline intrusions and the enrichment is related to hydrothermal activities. Volatiles played an important role in the evolution of highly evolved peralkaline rocks. The parent melts of the peralkaline rocks were generated under relatively dry and reduced conditions when these magmas undergo extensive fractionation accompanied by aqueous fluids in very late crystallization history (Dostal, 2016). At these advanced stages of fractionation, the aqueous fluids escape from a magma highly enriched in incompatible elements such as REE, HFSE, Th and U containing significant amounts of halogens, particularly fluorine (Dostal, 2016). Thus the hydrothermal fluids, which are enriched in all these elements, can play an important role in concentrating HFSE, REE, Th, and $\mathrm{U}$ as well as during autometasomatism. It appears that both magmatic and hydrothermal processes are likely to have contributed to the formation of the rare metal deposits of peralkaline rocks.

The deposits related to layered silicaundersaturated syenite complexes display various indications of crystal accumulation associated with layers rich in REE-bearing minerals (Ilimaussaq Complex). On the other hand, in pegmatites like at Strange Lake, intrusions at Khalzan Buregtei, and felsic dikes at Bokan Mountain, there are no obvious indications of crystal accumulation. The primary magmatic mineralization is probably related to the crystallization of highly fractionated, latestage, fluorine-rich peralkaline magma in pegmatites, minor intrusions, and dikes. At the Bokan Mountain deposit the mineralization is associated with altered zones and composed of secondary minerals, which pseudomorphically replaced primary minerals. The secondary hydrothermal processes played an important role.

All these deposits typically show imprints of hydrothermal processes that led to the remobilization of REE, HFSE, $U$, and Th and their redeposition in the nearby mineralized sites as secondary phases. The secondary processes not only redistributed but also enriched REE in the mineralized zones. During remobilization, LREE moved greater distances than HREE inferred that the remobilization took place at low temperatures $\left(<350^{\circ} \mathrm{C}\right)$.

The metasomatism at the Ulaan Del area expressed in albititization of syenite and microsyenite (trachyte, trachyrhyolite). The albititized rocks have elevated by REE mineralization. 
Magmatic-metasomatic-hydrothermal

processes played significant role in formation of REE mineralization at the Ulaan Del deposit

The Ulaan Del REE deposit is located within the Lake Zone, where the well-studied Khalzan Buregtei Nb-ZR-REE deposit is also located. The genesis and ore formation of both Ulaan Del and Khalzan Buregtei deposits may be similar, regarding their spatial and close locality and the $\mathrm{Zr}-\mathrm{REE}$ mineralization type.

According to the research works conducted at the Khalzan Buregtei deposit, enrichment in $\mathrm{Zr}$, $\mathrm{Hf}, \mathrm{Nb}$, Ta, REE, Y-HFSE was related to both magmatic and hydrothermal processes (Kempe et al., 2014). But, the magmatic and hydrothermal processes developed during different and distinct events. Several distinct hydrothermal processes resulted in the formation of heterogeneous metasomatic rocks strongly enriched in HFSE. For example, a fluid, rich in carbonate and silica caused the development of $\mathrm{Zr}, \mathrm{Nb}$, and LREE rich ores in calcite-bearing alteration assemblages (Kempe et al., 1995, 1996, 1997, 1999 and 2014). Late alteration by F-rich fluids resulted in some remobilization of HFSE and significant local enrichments of HREE and $\mathrm{Y}$ in the ores. The interplay of all processes resulted in the formation of a complex, economic $\mathrm{Zr}-\mathrm{Nb}$-REE mineralization at the Khalzan Buregtei (Kempe et al., 2014).

Petrographical, mineralogical and geochemical data and a comparison with the Khalzan Buregtei deposit suggested that $\mathrm{Zr}-\mathrm{Nb}-\mathrm{REE}$ mineralization of the Ulaan Del deposit may have been related to magmatic-metasomatichydrothermal processes during multiple events of alkaline magmatism.

\section{CONCLUSION}

REE-bearing dykes at the Ulaan Del deposit are silicified and albititized syenite and microsyenite (trachyte, trachyrhyolite).

Geochemically the dykes of the Khalzan Complex are presenting calc-alkaline high-K to shoshonite series, with ASI 0.6-1.1, related to A -type rocks formed within plate setting. Syenitic rocks are REE enriched and contain HREE and LREE mineralization.

REE ore bearing minerals at the Ulaan Del deposit are zircon, apatite, sphene, monazite, xenotime, synchysite, parisite, fluorite, REE complex minerals and also pyrite, rutile and limonite. REE grades are not even but with constant $>0.19 \% \mathrm{Zr}$ and $\mathrm{REE}>0.1 \%$.

\section{ACKNOWLEDGEMENTS}

I gratefully acknowledge Professors O.Gerel, B.Munhtsengel and B.Batkhishig for their constructive advice and reviews helped to progress the paper and to acknowledge the efforts of field geologists during the earlier field investigations. Special thanks to Professor L.P.Richvanov and Mr. G.Oyunbolor who provided Neutron activation analyses.

\section{REFERENCES}

Badarch, G., Cunningham, W.D., Windley, B.F. 2002. A new terrane subdivision for Mongolia: implications for the Phanerozoic crustal growth of Central Asia. Journal of Asian Earth Sciences, v. 21, p. 87-100. https:// doi.org/10.1016/S1367-9120(02)00017-2

Bonin, B. 2007. A-type granites and related rocks: Evolution of a concept, problems and prospects, Lithos, v. 97(1-2), p. 1-29. https:// doi.org/10.1016/j.lithos.2006.12.007

Civetta, L., D'Antonio, M., Orsi, G., Tilton, G.R. 1998. The Geochemistry of Volcanic Rocks from Pantelleria Island, Sicily Channel: Petrogenesis and Characteristics of the Mantle Source Region. Journal of Petrology, v. 39(8), p. 1453-1491. $\quad$ https://doi.org/10.1093/ petroj/39.8.1453

Dostal, J., 2016. Rare Metal Deposits Associated with Alkaline/Peralkaline Igneous Rocks. Reviews in Economic Geology, v. 18, p. 33-54. https://doi.org/10.5382/Rev.18.02

Gavrilov, O.I., Bajin, Yu., Kireev, A., Stolbov, V.P. 1987. Report on results of complex aerogeophysical mapping on scale 1:50000 conducted in 1987 in Achit Nuur area, western part of PR of Mongolia, Report No4185. (in Russian)

Gavrilov, O.I., Skornyakov, Yu., Gruzdeva, E., Dundukov, N. 1990. Report on results of complex aerogeophysical mapping on scale 1:50000 in Zavhan and Uvsnur aimaks, of PR of Mongolia, Report No4364. (in Russian)

Gavrilov, O.I., Stolbov, V., Chuvilin, V. 1989. 
Report on results of complex aerogeophysical mapping on scale 1:50000 in Uvsnur aimak, of PR of Mongolia, Report No4289. (in Russian)

Jahn, B.M., Litvinovsky, B.A., Zanvilevich, A.N., Reichow, M. 2009. Peralkaline granitoid magmatism in the MongolianTransbaikalian Belt: Evolution, petrogenesis and tectonic significance, Lithos, v. 113, p. 521-539.https://doi.org/10.1016/ j.lithos.2009.06.015

Kempe, U., Belyatsky, B., Dandar, S. 1996. Datierung der $\mathrm{Nb}$-Zr-REE mineralisationen von Khaldzan Buregte (Mongolischer Altai). European Journal of Mineralogy, v. 8(1), p. 135

Kempe, U., Dandar, S. 1995. Nb-Zr-REE mineralization: a possible source of HREE, in Pašavá, J., Křibek, T., Žák, P. eds., Mineral Deposits: from Their Origin to Their Environmental Impacts. Balkema, Rotterdam, p. 463-466.

Kempe, U., Goldstein, S., Dandar, S. 1997. An unusual metasomatic calcite from Tsakhir (Mongolia): Implications for REE-balance in $\mathrm{Nb}-\mathrm{Zr}$-REE mineralization. Kherlen International Geological Expedition, 11th International Scientific Conference. Technical University, Ulaanbaatar, v. 11. p. 52-54.

Kempe, U., Götze, J., Dandar, S., Habermann, D. 1999. Magmatic and metasomatic processes during formation of the $\mathrm{Nb}-\mathrm{Zr}-\mathrm{REE}$ deposits Khaldzan Buregte and Tsakhir (Mongolian Altai): indications from a combined CL-SEM study. Mineralogical Magazine, v. 63 (2), p. 165-177. https:// doi.org/10.1180/002646199548402

Kempe, U., Mockel, R., Graupner, T., Kynicky, J., Dombon, E. 2014. The genesis of Zr-NbREE mineralization at Khalzan Buregte (Western Mongolia) reconsidered, Ore Geology Reviews, v. 64, p. 602-625. https:// doi.org/10.1016/j.oregeorev.2014.05.003

Kovalenko, V.I., Pukhtel I.S.,Yarmolyuk V.V., Zhuravlev D.Z., Stosch H., Jagoutz E. 1995. The Sm-Nd isotopic systematics of ophiolites in the ozernaya zone (Mongolia). Stratigraphy and Geological Correlation, v. 4(2), p. 107113 (in Russian).

Kovalenko, V.I., Tsaryeva, G.M., Goreglyad,
A.V., Yarmoluk, V.V., Troitsky, V.A. 1996. The peralkaline granite-related KaldzanBuregtey rare metal ( $\mathrm{Zr}, \mathrm{Nb}, \mathrm{REE})$ deposit, Western Mongolia. Economic Geology, v, 90, p. 530-547. https://doi.org/10.2113/ gsecongeo.90.3.530

Kovalenko, V.I., Yarmolyuk, V.V., Sal'nikova, E.B., Kartashov, P.M., Kovach, V.P., Kozakov, I.K., Kozlovskii, A.M., Kotov, A.B., Ponomarchuk, V.A., Listratova, E.N., Yakovleva, S.Z. 2004. The KhaldzanBuregtei Massif of Peralkaline Rare-Metal Igneous Rocks: Structure, Geochronology, and Geodynamic Setting in the Caledonides of Western Mongolia. Petrology, v. 12(5), p. 412-436 (in Russian).

Kroener, A., Windley, B.F., Badarch, G., Tomurtogoo, O., Hegner, E., Jahn, B.M., Gruschka, S., Khain, E.V., Demoux, A., Wingate, M.T.D. 2007. Accretionary growth and crustal formation of the Central Asian Orogenic Belt and comparison with the Arabian-Nubian Shield, in Hatcher, R.D., Jr Carlson, M.P., McBride J.H., and Martinez Catalin J.R. eds., 4-D Framework of Continental Crust: Geological Society of America Memoir 200, p. 181-209. https:// doi.org/10.1130/2007.1200(11)

Le Maitre, R.W. 1989. A classification of igneous rocks and glossary of terms: recommendations of the International Union of Geological Sciences Subcommission on the Systematics of Igneous Rocks, Oxford, Blackwell, $193 \mathrm{p}$.

Lynch, D.J., Musselman, T.E., Gutmann, J.T., Patchett, P.J. 1993. Isotopic evidence for the origin of Cenozoic volcanic rocks in the Pinacate volcanic field, northwestern Mexico, Lithos, v. 29(3-4), p. 295-302. https:// doi.org/10.1016/0024-4937(93)90023-6

Marks, M., Markl, G. 2001. Fractionation and assimilation processes in the alkaline augite syenite unit of the llimaussaq Intrusion, South Greenland, as deduced from phase equilibrium. Journal of Petrology v. 42, p. 1947-1969. $\quad$ https://doi.org/10.1093/ petrology/42.10.1947

Minin, A.D., Mironov, Yu.B. 1991. Geological setting and mineral resources of Altan Huhei mountain range and its eastern margin in 
Western Mongolia. Report on results of geological mapping on scale 1:50000 conducted in 1989-1990. Nomenclature M-46 -100-B,G; M-46-112-A,B,V, G; M-46-124G,B,V,G; v. 1, p. 133-169 (in Russian) .

Oyunbat, S., Davaasambuu, D., Azzaya, A. 2018. Results on exploration of the Ulaan Del Zr-REE deposit during 2010-2017 (reserves/ resources by 1 Oct, 2017). Report No8551 (in Mongolian).

Platt, R.G. 1996. Nepheline-syenite complexean overview, in R.H.Mitchbell ed., Undersaturated Alkaline Rocks: Mineralogy Petrogenesis, and Economic Potential. Short volume 24, Ottawa, Mineralogical Association of Canada, p 63-100.

Ronga, F., Lustrino, M., Marzoli, A. 2010. Petrogenesis of a basalt-comenditepantellerite rock suite: the Boseti Volcanic Complex (Main Ethiopian Rift). Mineralogy and Petrology, v. 98, p. 227-243. https:// doi.org/10.1007/s00710-009-0064-3

Rudnev, S.N., Izokh, A.E., Borisenko, A.S., Shelepaev, R.A., Ori-hashi, Y., Lobanov, K.V., Vishnevsky, A.V. 2012. Early Paleozoic magmatism in the Bumbat-Hairhan area of the Lake Zone in western Mongolia (geological, petrochemical, and geochronological data). Russian Geology and Geophysics (Geologiya i Geofizika) 53 (5), 425-441 (557-578) (in Russian). https:// doi.org/10.1016/j.rgg.2012.03.004

Rudnev, S.N., Izokh, A.E., Kovach, V.P., Shelepaev, R.A., Terenteva, L.B. 2009. Age, composition, source and geodynamic environments of the origin of granitoids in northern part of Lake Zone, Western Mongolia, Petrology, v. 17(5), p. 470-508 (in Russian). https://doi.org/10.1134/ S0869591109050026

Samozvantsev, V.A., Zukernik, A.B., Golyakov, V.I., Baatarhuyag, G., Huppenen, T.P., Aphonin, V.V., Byamba, B., Ivanov, Yu.L.,
Kravtsev, A.V., Smirnov, I.G. 1982. Report on results of geological and aerophotogeological mapping on 1:200000 scale conducted in the territories of Lake Zone and western margin of Khangai mountain, Peoples Republic of Mongolia in 1978-1981. Report No3576 (in Russian).

Sisson, T.W., Ratajeski, K., Hankins, W.B. 2005. Voluminous granitic magmas from common basaltic sources. Contributions to Mineralkgy and Petrology v. 148, p. 635-661. https://doi.org/10.1007/s00410-004-0632-9

Soejono, I., Buriánek, D., Svojtka, M., Žáček, V., Cáp, P., Janoušek, V. 2016. MidOrdovivian and Late Devonian magmatism in the Togtokhinshil Complex: new insight into the formation and accretionary evolution of the Lake Zone (western Mongolia), Journal of Geosciences, v. 61, p. 5-23. https:// doi.org/10.3190/jgeosci.208

Sun, S.S., McDonough, W.F. 1989. Chemical and isotopic systematics of ocean basalts: implications form mantle composition and processes. In Saunders, A.D., Norry, M.J. (Eds) Magmatism in the ocean basins, Geological Society Special Publication, v. 42, p. 313-345. $\quad$ https://doi.org/10.1144/ GSL.SP.1989.042.01.19

Thorpe, R.S., Tindle, A.G. 1992. Petrology and petrogenesis of a Tertiary bimodal doleriteperalkaline/subalkaline trachyte/ rhyolite dyke association from Lundy, Bristol Channel. UK. Geological Journal, v. 27, p. 101-117. https://doi.org/10.1002/ gj.3350270202

Yashina R.M. 1982. Alkaline magmatism in folded belts. Nauka, p. 149-161 (in Russian). 